\title{
Exploiting Phonetic Exercise to Improve Students' Pronunciation Ability
}

\author{
Ana Ahsana El Sulukiyyah \\ STKIP PGRI PASURUAN \\ Pasuruan, Indonesia \\ aahsana3@gmail.com
}

\author{
Mardiningsih \\ STKIP PGRI PASURUAN \\ Pasuruan, Indonesia \\ niningatria20@gmail.com
}

\begin{abstract}
Pronunciation, sometimes become a forgotten skill in teaching and learning English. Teachers are reluctantly drilling their students' pronunciation. It is because the English pronunciation is not regular, so both students and teachers need long time to study about it. The problem about pronunciation was also happened in the fourth semester students of English Education Study Program in STKIP PGRI Pasuruan. Phonetic transcription exercise was the way used to improve the students' pronunciation ability. This is a Classroom Action Research where students were given two kind of tests, reading aloud test and phonetic transcription test. Questionnaires were also given to the students to know their response about phonetic transcription exercises. The results showed that for the first cycles some students still make mistakes in pronouncing some words given although they have known the phonetic visualization, but in the second cycle, there was a significance improvement of pronunciation ability, this is due to students have got accustomed to the phonetic symbols and could apply it to their pronunciation. It can be concluded that phonetic transcription exercises could improve students' pronunciation ability because it could show the precise visual written record of the sound itself.
\end{abstract} ability

Keywords-phonetic transcription exercise, pronunciation

\section{INTRODUCTION}

In teaching and learning English, four major skills are taught. They are reading and listening which are called as receptive skill and speaking and writing which are called as the productive skill. Pronunciation involves in teaching and learning speaking, because it is one of important parts in communicating [1]. Unfortunately, sometimes the teachers reluctantly drill their students' pronunciation ability. It is because the English sounds are not regular, we can say sound "o" in some other ways, can be $/ \alpha /$ or $/ \mathrm{c}: /$. Besides, to teach and learn pronunciation takes long time, teachers have to give example, the students imitate, then teachers drill the students, it needs more time and more practice [2]. That is why the students' pronunciation especially EFL students are still low.

The problems of students' pronunciation ability are also happened in the fourth semester students of English Education Study Program of STKIP PGRI Pasuruan. Although they can speak English fluently but they made mistakes in pronouncing some words, for word eight/8, they often pronounce it to $/ \mathrm{\varepsilon g} /$, of course it is sounded like egg, one of food kind. Another example is pronouncing word architect, they pronounce it to / $\alpha: \mathrm{fi}: \mathrm{tckt} /$ or
$/ \alpha: \int I t \varepsilon k t /$ but actually this word pronounce to / $\alpha: k I t \varepsilon k t /$. The teacher had done various ways to teach pronunciation, like using pronunciation software, drilling method, reading aloud and recording method. But those ways could not improve their pronunciation yet, because they only practice it in the class, then forget it out of class.

For the first time the teacher meet the students in Pronunciation class in the first semester, the students has got many exercises in pronouncing some words or sentences. Then the teacher meet again with them in this fourth semester in Phonology class, and their pronunciation ability is awful, only some students can pronounce the words or sentences correctly. Because in Phonology class description, teacher can remedy the students' pronunciation ability, it is the good time for teacher to remedy and improve their ability. The technique teacher uses in this semester is Phonetic Transcription Exercise.

Mompean and Lintunen [3] stated that it is advantageous to use phonetic symbols in teaching and learning English as Foreign language, this is due to students not only hear the sounds and its pronunciation but also know the symbols of the sounds visually. Not only hearing the sounds or audio example, students can imitate when the audio was played, but also visualizing the sounds, students know precisely how those sounds are pronounced [3].

Furthermore, introducing phonetic symbols to students have three steps [3], they are as the following: (a) select only English phonetics symbols, (b) get students' familiarity about the English symbols, (c) make phonetics symbols visually attractive, (d) make students perceive on the utility of phonetic transcription and (e) avoid their anxiety in learning the symbols. Atkielski [2] added that phonetic transcription can show the significant differences of the words' pronunciation, students can distinguish the sounds $/ \mathfrak{a} /$ with sounds $/ \varepsilon /$, sounds $/ \mathfrak{t} /$ with $/ \theta /$ precisely. They have listened to the example of words' pronunciation and added by the precise phonetic transcription that is why by using phonetic transcription exercises students can visually correct their pronunciation.

From the problems faced above, then the advantages found in exploiting phonetic transcription exercises to improve students' ability in pronouncing words or sentences, the researcher decided to gain the research question on how can phonetic transcription exercises be used to improve students' pronunciation ability? 


\section{A. Phonetic Transcription}

Phonetic transcription is a written record of sounds of spoken language. The relationship between phonetic transcription and spoken language is very similar to that between a printed musical score and a musical performance. Transcription separates pronunciation from actual audio recording, in reality it has many advantages for teaching spoken language and pronunciation [2]. Phonetic transcription does have a few drawbacks, the most significant of which is that it requires that both teachers and students be familiar with the IPA (or whatever system of transcription is used).

The activity of transcribing is very simple, the students must write the symbols of the sounds they have heard from the spoken language or from normal English orthography. Sometimes the transcriber cannot realize the letter they want to write, because English has irregular sounds. The International Phonetic Alphabet has hundreds of symbols, fifty from them are English sounds which are needed to the English phonetic transcription [4].

There are two styles of transcription that you may find useful in ESL/EFL classes. The first is called narrow transcription: it's transcription that attempts to record every single phonological feature (sound) of an utterance, whether it is important to meaning or not. Narrow transcription is useful mainly when you are trying to show students their own foreign accents, or when you are contrasting accents of English or comparing pronunciation of English with pronunciation of other languages [5].

Furthermore, Hesselwood [5] stated that the second form of transcription is referred to as broad transcription. It documents only the sounds that are important to meaning. This type of transcription is also called phonemic transcription. Broad transcription is used to show students how something should be pronounced. It emphasizes only the sound differences that serve to distinguish meaning; tiny pronunciation features that merely betray a foreign or regional accent are not transcribed. Broad transcription is the type you would use in pronunciation keys, and indeed dictionaries use broad transcription to show the pronunciation of words.

In this research, researcher uses the kind of narrow transcription which only directly transcribes the phonological features without its meaning.

\section{B. Teaching Pronunciation}

Winiewska [6] stated in her article about methods and techniques to teach pronunciation that phonetic transcription is one of the technique teachers' can use in the class of pronunciation. It is because phonetic transcription shows code and symbols of the sounds. Here are some methods and techniques teachers can use in pronunciation classes:

1) Phonetic transcription, it is represent the true sounds from different letters of alphabet. Many linguists believe that it is a good and valuable tool to learn foreign language sounds system.

2) Auditory reinforcement, the technique is useful for making learners aware of troublesome sounds through listening and discrimination practice.
3) Visual reinforcement, it is a real time visual displays are to show learners the relationship between the patterns they produce and those they are required to repeat. One of the possible conventions for making the word stress visible is writing the stressed syllable in capital letters:

\section{FAshion, SEssion, beHAVE}

Another common way of visualising word stress is the use of dots. The large dots mark a stressed syllable in a word: catwalk - $\bullet$.

4) Tactile reinforcement, it is the use of the sense of touch is another frequently employed technique, though it is not discussed very often. In fact, some teachers might be taking advantage of it without even realising this.

In Kenworthy [7] explained that teaching pronunciation is integrated with other skills of English. For example, in teaching listening, teachers cannot avoid the pronunciation activity. It is happened in teaching vocabulary too, teachers must give students example on how the words must be pronounced. The followings are the techniques teachers can use in pronunciation classes based on Kenworthy [7]: (i) Exploiting transcriptions of recorded materials, here teachers can give students recorded materials and show the phonetic transcription to make students aware how the words or phrases or sentences are pronounced. (ii) Actions replay technique, it is recording technique while students or learners are practicing speaking performance. Their activity are recorded, then it is replayed, and analyzed what are the errors of pronunciation they made during the action or performance. (iii) Oral homework, here students are asked to record their voices while pronouncing some words/phrases/sentences. The recordings will be brought to a class small discussion needed to analyze the pronunciation errors.

Teachers in foreign learning situation of course have done some similar techniques and methods stated above. EFL students have also been accustomed by the pronunciation activity. It is effected their English speaking performance and their performance in comprehending the content in listening activity.

\section{METHOD}

This research is a Classroom Action Research. As stated in Latief [8], Classroom Action Research is for English learning aims at discovering learning teaching strategies that match learner's style and strategies in learning English. It is also the effective media to improve the English teacher's performance quality. The research was conducted in English Education Study Program of STKIP PGRI Pasuruan. There are two classes for 2016 generation for English Phonology class. The researcher chose class 2016 B consists of 25 students, because from the data got this class has problems in pronouncing English words, but they are interested in learning and remedying their pronunciation ability.

The data gained from a questionnaire given in preliminary study. It was formulated that the most factor of pronunciation problem is lack of practicing and reluctant to find and search for the correct pronunciation, in other word, the students got fossilize with their own way pronunciation. Badly, they did not 
realize that they pronounce incorrect English sounds. Based on this problem, the researcher chose phonetic transcription exercises to improve students' pronunciation ability. The Criteria of Success of this research is $100 \%$ students got 80 in pronouncing 30 words after being given phonetic transcription exercises.

The instruments of this research are: test and documentation, they were used to gain the data of the students' pronunciation ability. In advance of the research, the cycle period could not be predicted. This research took two cycles then, because the first cycle was failed. The researcher revised some steps to gain better data.

\section{RESULTS AND DISCUSSION}

\section{A. Results}

In the first cycle, the researcher gave some example of phonetic transcriptions before giving the students exercise. The students must be accustomed to the IPA symbols and how to transcribe. For the first meeting, the students were given exercises to transcribe one syllable word as the following:

TABLE I. ONE Syllable Word to BE PRONOUNCED

\begin{tabular}{|l|l|l|l|l|}
\hline book & bed & bit & back & beat \\
\hline deck & duck & dog & door & dumb \\
\hline good & goose & give & got & gum \\
\hline hook & hack & hole & have & him \\
\hline jug & joke & jerk & jump & jew \\
\hline
\end{tabular}

Then, the students were given the answers to practice their pronunciation in the second meeting. The reading aloud test was conducted individually. It took lot of time, and here are the findings:

CHART 1 STUDENTS' SCORE IN CYCLE 1

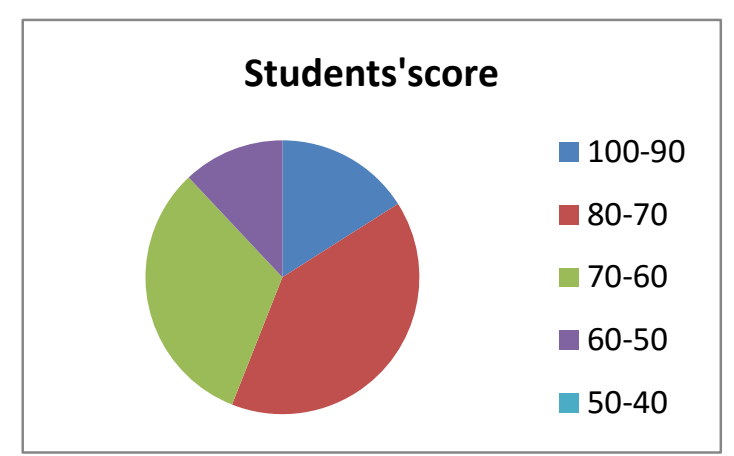

We could see from the biggest part of the chart, it was shown that almost half of students got 60-70 score in pronouncing those words. Whereas, criteria of success is all the students got 80 as the minimum score to be called pass in the test of pronouncing the words after being given of phonetic exercises. Thus, the second cycle was conducted.

In the second cycle, the researcher directly gave the students two exercise, first the exercise from normal English orthography, then to the phonetic exercise, here were the exercises:
TABLE II. WORDS PRONOUNCED

\begin{tabular}{|l|l|l|l|}
\hline life & toothpaste & electric razor & atmosphere \\
\hline picture & shampoo & toothbrush & rug \\
\hline comfortable & razor & radiator & lamp \\
\hline perfume & brush & cushion & sofa \\
\hline
\end{tabular}
A. Aat'
B. $r$ 'piktferf
C. f'kofi 'teiby
D. /pa'fjum/
E. f'tu:Opeist
F. Jrem'pu:
G. 'relzar'
H. /bralt
I. A'lektrik 'reizart
J. f'tu:ebrayl
K. f'reidieitarf
L. $r$ 'kufn
M. ${ }^{\prime}$ a:mifeart
N. $/ \mathbf{r a g} f$
O. Aremp
P. f'seufer

The students were more enthusiastic in doing these tasks because they realized that the words were the same after doing both of them. They could directly remedy their pronunciation. Then the researcher test them individually to pronounce the words and this is the result:

CHART II STUDENTS' SCORE IN CYCLE II

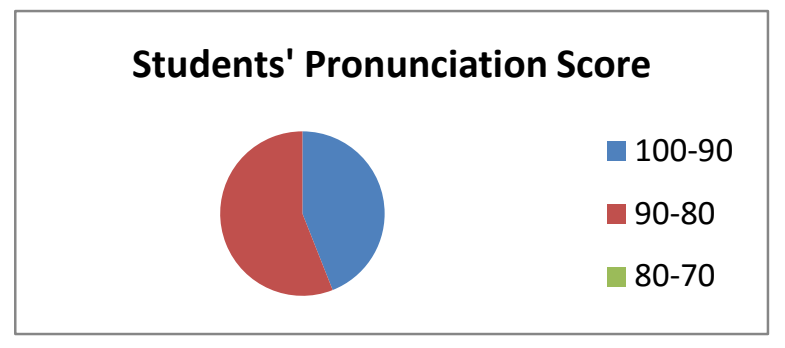

It was shown that, more than half of students got 80-90, and the rest got 90-100. The second cycle was succeeded because it could reach the criteria of success of $100 \%$ students got 80 in pronouncing the words after being given the phonetic transcription exercise.

\section{B. Discussion}

This research was succeeded in the second cycle. The researcher will explain and analyze the reasons and the result. In cycle two, students had accustomed to the phonetics transcription exercises, they were able to correct their errors by themselves by seeing the transcription exercises. It is in line with Hesselwood [5] where students and teachers do not need much time to teach pronunciation, without too many "repeat after me" direction, students were able to remedy their pronunciation. That is one of advantages teachers and students can get in using transcription exercises.

Besides, Winiewska [6] stated that phonetic transcription exercise is one of tool can be used by teachers in pronunciation classes. It is valuable for students in knowing the precise symbols of sounds in the foreign language sound system. It was 
happened in the research, students were amazed by the sounds they have not known before. They knew the differences of some similar sounds by looking at the symbols of the phonetic transcription exercises. They directly corrected their errors spontaneously because they remembered the symbols they have done in phonetic transcription exercise.

In other words they aware to the pronunciation of the words because they have known the transcription. It is in line with Kenworthy [7] in which exploiting transcription exercises can make students aware how the words must be pronounced. Students awareness were improved, it was also increase their pronunciation ability. They pronounced the words precisely after knowing the transcription. It made the second cycle successfully improved the students' pronunciation ability by using the phonetic transcription exercises.

\section{CONCLUSION}

The researcher concludes that exploiting phonetic transcription exercises can improve students' pronunciation ability. It was exploited in two cycles, but the first cycle was failed, it could not reach the criteria of success. Then, thebsecond cycle was implemented, it worked better and gave significance improvement of the pronunciation ability of fourth semester students in English Education Study Program of STKIP PGRI Pasuruan.

\section{REFERENCES}

[1] F. L. Schmidt, "The problem of group differences in ability scores in employment selection," Journal of Vocational Behavior, vol. 33, pp. 272292, 1992.

[2] A. Atkielski, "Using phonetic transcription in class," October 2012

[3] A. J. Mompen and P. Litunen, "Phonetic notation in foreign teaching and learning potential advantages and learners," vol. 3, no. 3, 2015.

[4] J. C. Wells, "Phonetic transcription and analysis transcription," University College London, May 2018.

[5] B. Hesselwood, "Phonetic transcription in theory and practice," Edinburgh University, 2013.

[6] H. Winiewska, "Methods and techniques in pronunciation teaching," 2000 .

[7] J. Kenworthy, "Teaching English pronunciation," New York: Longman Inc., 2005.

[8] M. A. Latief, "Research methods on language learning: An Introduction," Malang: Universitas Negeri Malang, 2012. 